\title{
The Influence of Visionary Leadership Style on Organizational Commitment of Private University Lecturers
}

\author{
Basri 1, Rosmala Dewi 2, Saud Purba 3 \\ DOI : $10.35445 /$ alishlah.v13i3.730
}

Article Info

Key words:

Leadership; Orqanizational commitment; Lecturers

Kata kunci:

Kepemimpinan; Komitmen Organisasi; Dosen

\section{Abstract}

Good leadership is one of the virtues that need to exist in an organization. In carrying out the roles, duties, and responsibilities, every leader has their leadership style. This study aims to investigate the effect of visionary leadership style on organizational commitment. The study used quantitative methods with ex post facto research. The investigation begins after the facts have already occurred, and the researchers do not control nor manipulate the variables studied. The population in this study consisted of 294 lecturers, with a sample size of 169 people. The instrument used in this research was a questionnaire. The data analysis utilized was simple linear regression analysis processed by the SPSS. Findings show that the variable visionary leadership style (X) positively influences the variable organizational commitment of private university lecturers in Banda Aceh City. The results obtained are $t_{\text {coumt }}>t_{\text {table }}$ or $8.741>1.974$. In addition, there is a strong relationship or correlation between variables $\mathrm{X}$ and $\mathrm{Y}$ of $56 \%$ and the coefficient of determination ( $R$ Square) of .314, indicating that there is an influence of the independent variable (visionary leadership style) on the dependent $v$ ariable (organizational commitment) of $31.4 \%$.

\begin{abstract}
Abstrak
Peranan kepemimpinan merupakan salah satu keutamaan yang harus ada dalam suatu organisasi. Dalam melaksanakan peran, tugas dan tanggung jawab maka setiap pemimpin memiliki gaya tersendiri dalam kepemimpinannya. Tujuan dalam penelitian ini adalah untuk mengetahui pengaruh gaya kepemimpinan visioner terhadap komitmen organisasi. Metode yang digunakan dalam penelitian ini berupa kuantitatif dengan penelitian ex post facto yaitu variabel-variabel yang diteliti tidak dikendalikan dan dimanipulasi oleh peneliti, tetapi fakta diungkapkan berdasarkan pengukuran gejala yang telah dimiliki atau menguji apa yang akan terjadi. Populasi dalam penelitian ini terdiri dari 294 dosen, sehingga sampel yang diambil sebesar 169 orang. Instrumen yang digunakan dalam penelitian ini berupa angket atau kuesioner. Teknik analisis data menggunakan analisis regresi linear sederhana berbantuan SPSS. Hasil penelitian menunjukkan bahwa terdapat pengaruh positif dan signifikan antara variabel gaya kepemimpinan visioner (X) terhadap variabel komitmen organisasi Dosen PTS di Kota Banda Aceh. Hasil yang diperoleh yaitu $t_{\text {hitung }}>t_{\text {tabel }}$ atau 8,741 $>1,974$. Selain itu, terdapat hubungan atau korelasi yang kuat antara variabel $\mathrm{X}$ dan $\mathrm{Y}$ sebesar $56 \%$ dan koefesien determinasi ( $R$ Square) sebesar 0,314 yang berarti terdapat pengaruh variabel bebas (gaya kepemimpinan visioner) terhadap variabel terikat (komitmen organisasi) adalah sebesar $31,4 \%$.
\end{abstract}

\footnotetext{
${ }^{1}$ Un iv ersitas Jabal Ghafur, Aceh , Indonesia

Em ail: basriunigha@gmail.com

2 Universitas Negeri Medan, Indonesia

Em ail: ros_dw@yahoo.com

3 Un iv erssitas Negeri Medan, In donesia

Em ail: sautpurbapurba@gmail.com
} 


\section{INTRODUCTION}

The world today is experiencing rapid developments in various fields that bring competition among countries worldwide. Science and technology, in particular, have been developing very fast, and they have been influencing people to possess the quality and ability to think critically, creatively, and innovatively. Wijaya et al. (2016) state that the 21st century demands quality human resources that professionally managed institutions produce. One of the formal educational institutions essential in producing quality resources is higher education institutions (Kemal et., 2019).

Improving the quality of human resources through education starting from primary and secondary to tertiary education is the key to effectively following the Industrial Revolution 4.0 (Mardhiyah et al., 2021). Improving the quality of human resources is also inseparable from the skills and abilities of educators in delivering learning material needed to develop superior and skilled human resources. The implementation of the educational process, especially in higher education, is highly influenced by the leadership style applied at the university .

Leaders are commonly interpreted as trusted people to take care of and manage an organization (Haris, 2018: 6). Leadership is often associated with the skills, abilities, and levels of influence (Dirham, 2019). Leadership is also referred to as a creative, aspirational force, spirit power, and moral strength, which can influence members to change attitudes to align with a leader's will and aspirations (Mulyono, 2018). Leadership, by nature, is the influence applied by a member of a group or an organization to other members to achieve the group's goals (Hajar et al., 2018). Having leadership in an organization, such as an educational institution, will influence its subordinates to obtain effective performance so that the predetermined goals can be achieved.

Due to the role and function of leadership in an educational institution, leadership style may vary from one person to another. One of the typical leadership styles applied at the university level is visionary leadership. Visionary leadership focuses on creating and articulating a clear vision and giving meaning and purpose to the organisation's work (Nwachukwu et al., 2017). Visionary leadership is the act of a leader to influence or encourage others to create and articulate realistic, credible, and exciting visions of the future that can improve current circumstances, with the following indicators: setting superior standards and reflecting high ideas, clarifying goals and directions, arousing enthusiasm and maintaining commitment, having good and easy to understand utterances (effective communication), reflecting the uniqueness of the organization and different competencies, and possessing a solid determination to realize the ideals (Anshar, 2017).

Visionary leadership can affect the organizational commitment of an educator or a lecturer in a university. Thus, a leader's leadership style in higher education can influence the commitment of lecturers or subordinates. Consequently, this will impact the improvement of the quality of universities, in this case, private universities. Simbolon (2017) describes that leadership in private universities requires an understanding of the principles of visionary leadership to face increasingly complex challenges and competitiveness.

The problem in leadership is that the leadership style has not yet been clarified, and the achievement of the vision has not yet been carried out by the officeholders, who have been inaccurate in delegating authority and slow in making decisions, which has resulted in issues with student achievement. A similar pattern can be found in Taruno's study, et al. (2012) about the performance of lecturers, particularly in terms of teaching performance, as demonstrated by: a lack of preparation of material or outsourcing teaching assignments to assistants. A study conducted by Indrarini (2009) describes the implementation of research and scientific publications in individual and group research. It is still below average due to a lack of research culture, insufficient ability to compile research proposals, and a lack of relevance of research about the needs of influential people who have a say in the performance of community service organizations. 
Preliminary observations at several private universities in Banda Aceh City have shown that the leadership style of superiors can affect lecturers' organizational commitment. It can help improve the skills and mindset of lecturers in achieving something that has been planned. A leader in a higher education setting should pay attention to the functions that transform the efforts of lecturers and students towards learning. Higher education leaders are expected to improve the performance of lecturers through various vital factors that support the continuity of the learning process, one of which is through visionary leadership.

Visionary leaders with their authority can create a working culture or climate that causes people who lack workplace ethics to have self-consciousness and, therefore, try to improve their performance (Thamrin, 2020). A government organization requires a leader to possess the ability to manage their subordinates to work well. Then they can find ways to improve the production and standards of the organization under their leadership.

\section{METHOD}

This study used quantitative methods with ex post facto research. The investigation begins after the facts have already occurred, and the researcher does not control nor manipulate the variables studied. The population in this study was private university lecturers in the guidance and supervision of LLDIKTI XIII Aceh. The private universities under LLDIKTI XIII Aceh have as many as 49 study programs, each of which has six permanent lecturers, thus totalling 294 lecturers. Utilizing the Slovin formula, the study obtained a sample size of 169 people. The instrument used in this study was a questionnaire. Data analysis employed was simple linear regression processed in the SPSS to measure the variable visionary leadership style (X) against the inconsistent organizational commitment (Y).

\section{FINDINGS AND DISCUSSION}

This study attempted to investigate the effect of the visionary leadership style on the organizational commitment of lecturers at private universities in Banda Aceh. To determine the effect of the variable $\mathrm{X}$ on $\mathrm{Y}$, a hypothesis test was conducted. Before carrying out a simple linear regression test or hypothesis testing, the classical assumption tests are a prerequisite for the testing.

\section{a. ClassicalAssumption Tests}

Classical assumption tests are conducted to determine whether or not there are classical assumption problems in a simple linear regression model. The issues in the classical assumption test in this study were analyzed in two stages, including normality and heteroscedasticity tests. Normality test is used to determine whether or not the dependent variable, the independent variable, or both are typically distributed. A good regression model should have a normal distribution or be unidentified through the Kolmogorov Smirnov test. The results of the Kolmogorov Smirnov test for normality can be seen in Table 1.

Table 1. Results of Kolmogorov-Smirnov Test for Normality

\begin{tabular}{ccc}
\hline & & Unstandardized Residual \\
\hline Normal Parameters ${ }^{\mathrm{a}, \mathrm{b}}$ & Mean & 169 \\
& Std. & .0000000 \\
& Deviation & 14.14345294 \\
Most Extreme & Absolute & .064 \\
Differences & Positive & .049 \\
& Negative & -.064 \\
Test Statistic & .064 \\
\hline \multicolumn{2}{c}{ Asymp. Sig. (2-tailed) } & $.085^{\mathrm{c}}$ \\
\hline
\end{tabular}


Table 1 displays that the normality test obtained a significance value of 0.085 for independent and dependent variables, and so the value of $0.085>0.05$, indicating that the residual value is of normal distribution.

The next classical assumption test is the heteroscedasticity test. The heteroscedasticity test assesses whether or not there is an inequality of variance from the residuals for all observations in the linear regression model. The heteroscedasticity test can be said to be valid or fulfilled if it is below 5\%. If the assumption of heteroscedasticity is not met, then the regression model is declared invalid as a forecasting tool. One of the requirements that must be completed in a good regression model is having no sign of heteroscedasticity. The results of the scatterplot heteroscedasticity test can be seen in Figure 1.

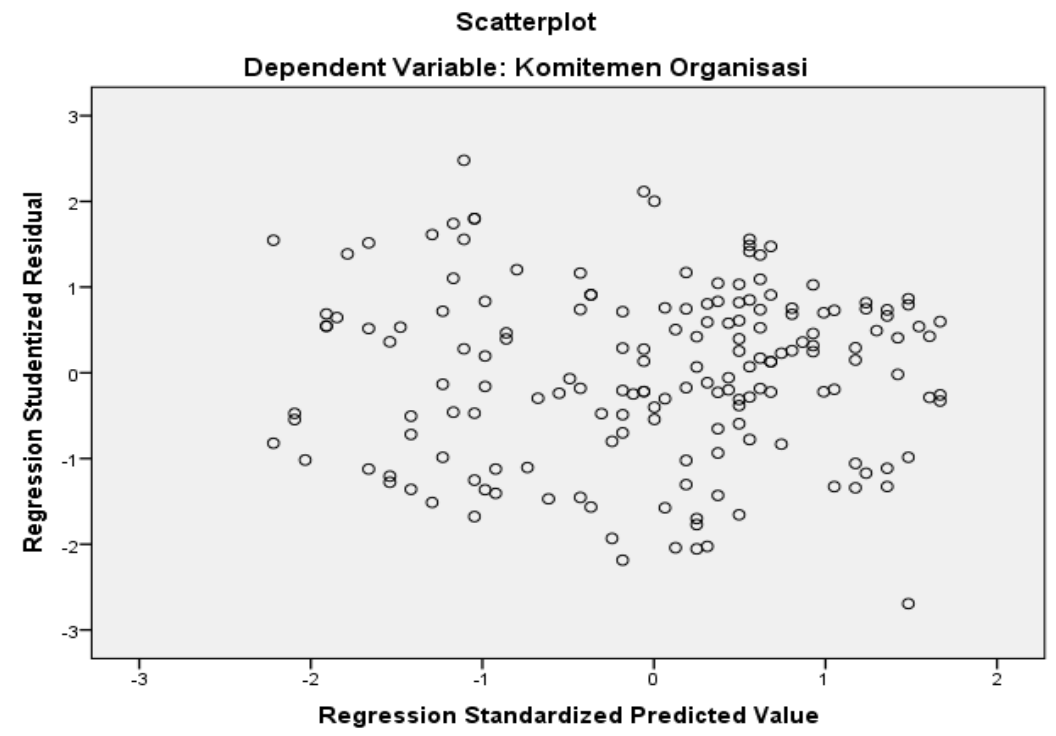

Figure 1. Results of Heteroscedasticity Test

Figure 1 shows that the scatterplot test analysis illustrates the absence of heteroscedasticity. As displayed above, the spread of data points does not form a wavy pattern, and it widens and then narrows and widens again.

\section{b. Simple Linear Regression Test}

From previous analyses, the study found that the requirements to perform a simple linear regression test have been met since the simple linear regression test obtained normal distribution and no heteroscedasticity. This study's simple linear regression model refers to a linear relationship between one variable, $\mathrm{X}$ in the form of innovative leadership style and $\mathrm{Y}$ variable of organizational commitment. The results of the output coefficient can be seen in Table 2.

Table 2. Simple Linear Regression Test

\begin{tabular}{llrrr}
\hline \multirow{2}{*}{ Model } & \multicolumn{2}{c}{$\begin{array}{c}\text { Unstandardized } \\
\text { Coefficients }\end{array}$} & \multicolumn{2}{c}{$\begin{array}{c}\text { Standardized } \\
\text { Coefficients }\end{array}$} \\
\cline { 2 - 5 } & \multicolumn{2}{c}{ B } & Std. Error & Beta \\
\hline \multirow{2}{*}{$\mathbf{n}$} & (Constant) & 59.280 & 8.238 & \\
\cline { 2 - 5 } & Visionary Leadership Style & .590 & .068 & .560 \\
\hline
\end{tabular}

The output results of the simple linear regression test showed a constant value (a) of 59.280 and a regression coefficient value (b) of .590. Here, the regression equation is written as follows:

$$
\begin{aligned}
& \mathrm{Y}=\mathrm{a}+b \mathrm{X} \\
& \mathrm{Y}=59.280+.590 \mathrm{X}
\end{aligned}
$$


The above equation can be interpreted as the following:

1) The constant is 59.280 , meaning that the constant value of the organizational commitment variable is 59.280 .

2) The regression coefficient $X$ of .590 states that in each additional $1 \%$ of the visionary leadership style value, the value of organizational commitment increases by .590 . The regression coefficient is positive, indicating that the influence of the variable $\mathrm{X}$ on $\mathrm{Y}$ is positive.

\section{c. Hypothesis Test (t-test)}

The results of the $t$-test aimed to determine the effect of the variable visionary leadership style on organizational commitment or to determine the significant level of individual independent variables on the dependent variable. If $t_{\text {count }}>t_{\text {table }}$, then $H a$ is accepted and $H o$ is rejected, and vice versa. The results of the $t$-test are shown in Table 3 .

Table 3. Results of $t$-Test

\begin{tabular}{|c|c|c|c|c|c|}
\hline \multirow[b]{2}{*}{ Model } & \multicolumn{2}{|c|}{$\begin{array}{c}\text { Unstandardized } \\
\text { Coefficients }\end{array}$} & \multirow{2}{*}{$\begin{array}{c}\text { Standardized } \\
\text { Coefficients }\end{array}$} & \multirow[b]{2}{*}{$\mathrm{t}$} & \multirow[b]{2}{*}{ Sig. } \\
\hline & $\mathrm{B}$ & Std. Error & & & \\
\hline (Constant) & 59.280 & 8.238 & & 7.196 & .000 \\
\hline $\begin{array}{l}\text { Visionary } \\
\text { Leadership Style }\end{array}$ & .590 & .068 & .560 & 8.741 & .000 \\
\hline
\end{tabular}

Table 3 shows that the value of $t_{\text {count }}>t_{\text {table }}$ or $8.741>1.974$; this indicates that the variable visionary style (X) affects the variable organizational commitment (Y).

\section{d. Determination Test $\left(R^{2}\right)$}

The coefficient of determination (adjusted $\mathrm{R}^{2}$ ) essentially measures to what extent the model's ability explains the variance in the dependent variable. The results of the coefficient of determination are provided in Table 4.

Table 4. Results of the Coefficient of Determination

\begin{tabular}{llrrr}
\hline Model & R & R Square & $\begin{array}{c}\text { Adjusted R } \\
\text { Square }\end{array}$ & $\begin{array}{l}\text { Std. Error of } \\
\text { the Estimate }\end{array}$ \\
\hline 1 & $.560^{\text {a }}$ & .314 & .310 & 14.186 \\
\hline
\end{tabular}

Table 4 explains the magnitude of the correlation or relationship (R) value of .560 and the coefficient of determination ( $R$ Square) of .314 . This implies that the influence of the independent variable (the visionary style) on the dependent variable (organizational commitment) amounted to $31.4 \%$, but the remaining $68.6 \%$ was affected by other variables.

This study analyzed the effect of the visionary leadership style (X) on organizational commitment $(\mathrm{Y})$. The results revealed a positive and significant influence between the visionary leadership style on the organizational commitment of private university lecturers in Banda Aceh City. Thus, it suggests that the better the leadership style applied, the higher the organizational commitment of private university lecturers in increasing their work potential. In addition, the study also found that the correlation between the visionary leadership style and organizational commitment reached 31.4\%, while other variables influenced the rest. In this case, the leadership style also plays an important role in strengthening university lecturers' commitment.

The findings conform to what Darmawan and Putri (2017) have pointed out: when leadership style can create a good and compelling atmosphere, lecturers will feel satisfied in their work, eventually making the lecturers more loyal to their job and not change their current position. Lecturers are an element of education that has a very strategic role in creating quality education and helps improve the image of higher education institutions wherein they work (Sukriadi, 2018). Therefore, the part of the visionary leadership style can help change the quality of lecturers in further their abilities and skills in their work environment. 


\section{CONCLUSION}

The study concludes that the visionary leadership style has a positive and significant effect on the organizational commitment of private university lecturers in Banda Aceh City. The results obtained are $t_{\text {count }}>t_{\text {table }}$ or $8.741>1.974$. In addition, there is a strong relationship or correlation between the variables $\mathrm{X}$ and $\mathrm{Y}$ of $56 \%$ and the coefficient of determination ( $R$ Square) of .314, which reflects that there is an influence of the independent variable (visionary leadership style) on the dependent variable (organizational commitment) of $31.4 \%$.

This research is expected to be an input for the organisation's leadership to build commitment and become a visionary leadership. Leadership training is indispensable in creating this goal. This research is still limited to the relationship of visionary leaders to organizational commitment. It has not been developed on research has not been developed on what aspects are the most dominant in this correlation. Therefore, this research can still be continued on other themes or aspects that affect the success of organizational commitmen.

\section{REFERENCES}

Anshar, M. 2017. The Impact of Visionary Leadership, Learning Organization and Innovative Behavior to Performance of Customs And Excise Functional. International Journal of Human Capital, 1(2):52-60. http://journal.unj.ac.id/unj/index.php/ijhcm/article/view/4757

Darmawan, A., \& Putri, A.M. 2017. Pengaruh Gaya Kepemimpinan terhadap Komitmen Organisasi Melalui Kepuasan Kerja Sebagai Variabel Intervening. Akuntabilitas: Jurnal Ilmu Akutansi, 10(1): http://journal.uinjkt.ac.id/index.php/akuntabilitas/article/view/6109

Dirham. 2019. Gaya Kepemimpinan yang Efektif. Dinamis: Journal of Islamic Management and Bussines, 2(1):1-8https://ejournal.iainpalopo.ac.id/index.php/dinamis

Hajar, S., Lubis, R, A., \& Lubis, H.P. 2018. Pengaruh Perilaku Kepemimpinan dan Kepercayaan terhadap Kinerja Dinas Sosial Tenaga Kera dan Transmigrasi Kabupaten Aceh Barat. Jurnal Magister Manajemen. 2(1): 4657.http://jurnal.unsyiah.ac.id/JMM/article/view/10241

Haris, Amin. 2018. Kepemimpinan Pendidikan. Bandung: Alfabeta.

Indrarini. (2009). Effect of Motivation and Job Satisfaction on the Performance of Private Academy Lecturers in Semarang City.

Kemal, Isthifa; Suryadi; Rosyidi, Unifah. 2019. Management of Lecturers Resource Development at Higher Education. International Journal of Higher Education, 8 (5): 246-256. https://doi.org/10.5430/ijhe.v8n5p246

Madhiyah, H.R; Aldriani, F.N.S; Chitta, F., \& Zulfikar, R.M. 2021. Pentingnya Keterampilan Belajar di Abad 21 sebagai Tuntutan dalam Pengembangan Sumber Daya Manusia. Lectura: Jurnal Pendidikan, 12(1):3040.https://journal.unilak.ac.id/index.php/lectura/article/view/5813

Nwachukwu, C., Chiladkova, H., Zufan, P., \& Olatunji, F. 2017. Visionary Leadership and Its Relationship to Corporate Social Performance. Imperial Journal of Interdisciplinary Research (IJIR), 3(4):1302-1311.

Sambolon, S. 2017. Pengaruh Kepemimpinan Visioner, Motivasi, dan Kompetensi terhadap Budaya Kerja dan Komitmen serta Implikasinya pada Kinerja Dosen. Jurnal Kontigensi, 5(2):8797. https://zenodo.org/record/3375297\#.YMl8LOBKjIU.

Sukriadi, H.E. 2018. Pengaruh Kepemimpinan Visioner Dan Motivasi Kerja Terhadap Kepuasan Kerja. The Journal : Tourism and Hospitality Essentials Journal, 8(2):139-146. https://ejournal.upi.edu/index.php/thejournal/article/view/13747 
Mulyono, H. 2018. Kepemimpinan (Leadership) Berbasis Karakter dalam Peningkatan Kualitas Pengelolaan Perguruan Tinggi. Jurnal Penelitian Pendidikan Sosial Humaniora, 3(1):290297.https://jurnal-lp2m.umnaw.ac.id/index.php/JP2SH

Taruno, FX. S. C., \& et al. (2012). Effect of Leadership Style on Lecturer Performance with Job Satisfaction and Work Motivation as a Mediator (Study at Private Universities in Jayapura). Management Application, 10 (3), 495-509.

Thamrin, R.J. 2020. Pengaruh Kepemimpinan Visioner dan Budaya Organisasi terhadap Kinerja Pegawai di Pemkot Cimahi. Jurnal Ekonomi \& Ekonomi Syariah, 3(1):124-137. https://stiealwashliyahsibolga.ac.id/jurnal/index.php/jesya/article/view/141

Wijaya, Y.E., Sudjimat, A.D., \& Nyoto, A. 2016. Transformasi Pendidikan Abad 21 sebagai Tuntutan Pengembangan Sumber Daya Manusia di Era Global. Prosiding Seminar Nasional Pendidikan Matematika 2016, Universitas Kanjuruhan Malang, 1:263-278. 